

\title{
Incorporating Architecture
}

\author{
Paul Walker
}

Any discourse must wrestle with the problem of its beginning and consequently the problem of its origin and of origins in general. Every textual beginning of necessity establishes its non-primary originality by inscribing a principle of repetition....

Explanations of the origins of architecture have repeatedly been presented as explanations of the origins of shelter, of building. Architecture is taken to be building, to have its origins and its ends in building. Architecture is a corpus of buildings, a canon of masterpieces. Or it is certain kinds of building; cathedrals say, but not bicycle sheds. Or refined or elegant or symbolic or meaningful building. Or decorated building. Whatever else architecture might be it is building, and its origins are one with those of building.

Near the end of On Adam's House in Paradise (we are dealing with mankind here) Joseph Rykwert writes that: 'The return to origins always implies a rethinking of what you do customarily, an attempt to renew the validity of your everyday actions, or simply a recall of the natural (or even divine) sanction for your repeating them for a season. In the present rethinking of why we build and what we build for, the primitive hut will, I suggest, retain its validity as a reminder of the original and therefore essential meaning of all building for people: that is, of architecture.' But this primitive hut, he writes, should not be taken '... as a shelter against the weather, but as a volume which he [Adam, man] could interpret in terms of his own body and which yet was an exposition of the paradisiacal plan, and therefore established him at the centre of it'.1

I want to place this in doubt, this pretence that we can always return immediately to the origin of our discourse, architecture, equated with the origins of building, whenever we feel need for recuperation. It is a pretence that history does not matter. I want to introduce this doubt by citing another text on the primitive, Claude Levi-Strauss's Tristes Tropiques. Lévi-Strauss gives a beautifully arcadian description of a village made by the Burmese Kuki tribe. 2 Their:

... houses were not so much built as knotted together, plaited, woven, embroidered, and given a patina by long use. Those who lived in them were not overwhelmed by great blocks of unyielding stone; these were houses that reacted immediately and with great flexibility to their presence, their every movement. The house was, in fact,

opp from D. Barbaro, I dieci libri (1556), verso of frontispiece
Paul Walker graduated from the University of Auckland with a PhD in Architectural Theory. Walker currently works for Ian Athfield Architects and lectures parttime at Victoria University in Architectural Theory and Criticism and Design. He will be a guest editor of $a$ future special issue of Interstices on Ornament.

1. Joseph Rykwert, On Adam's House in Paradise, New York: Museum of Modern Art, 1972; pp. 192 and 190 .

2. Claude Lévi-Strauss, $A$ World on the Wane, (translated from Tristes Tropiques, 1955), London: Hutchinson, 1961; pp. 198199. 
subject to the householder, whereas with us the opposite is the case. The village served the villagers as a coat of light elastic armour; they wore it as a European woman wears her hats. It was an object of personal adornment on a mammoth scale, and those who had built it had been clever enough to preserve something of the spontaneity of natural growth. Leafage and the springing branch were combined, in short, with the exactations of the carefully planned lay-out.

And when they went forth from their houses it was if they had just slipped out of an enormous dressing gown of ostrich feathers. Their houses were caskets lined with down, it might have seemed, and their bodies the jewels within them.

But however desirable these houses are, they are not the kind we know. Our architecture is not like this, even if one believes, as perhaps Lévi-Strauss does, that it properly should be. In a later chapter of Tristes Tropiques, the chapter titled 'The Writing Lesson', well known because of Jacques Derrida's attending to it in Of Grammatology, Lévi-Strauss writes briefly of the origins of architecture as we know it. He links these origins with the invention of writing, which for him would also be the invention of history and inequality and alienation and inauthenticity; writing made it 'possible to assemble work people by the thousand and set them tasks that taxed them to the limits of their strength: to this, surely, we must attribute the beginnings of architecture as we know it'.

But if there are differences between Lévi-Strauss and Rykwert - for the one paradise is a (sadly disappearing) reality from which we have long been excluded by the operation in our culture of writing, while for the other it is a fiction (sometimes a written fiction) with a power of renewal on which we can always call - they are alike insofar as both describe a very close relation between the primitive building, the essential building, and the bodies that occupy it. As close, perhaps, as the relation of the body and the soul.

It is the assumption of this close relation that makes the body so important a motif in architectural theory, for the architecture that links itself absolutely to the body, that appropriates the human body, is guaranteed privilege now and forever, for bodies are always and everywhere the same. A natural constant, so it is assumed.

Recently, writers and readers on architecture have taken up this theme again. Not a new book, but one that has recently been reread is Geoffrey Scott's The Architecture of Humanism, first published in 1914. Written as a defence of the classical architecture of the Renaissance, Scott's book attacks various views of architecture which he calls fallacies (romantic, mechanical, ethical and biological fallacies) which have their beginning mostly in the eighteenth century, but it also attacks overintellectualised theorising in general, including the codification of the orders of classical architecture and the Renaissance veneration of the Vitruvian text. Scott does not think much of Vitruvius, and argues that the pre-eminence of his status as 
a theorist (all Renaissance theory is perhaps to be read as a gloss on The Ten Books on Architecture) was a result of his text being fortuitously rediscovered at a time when printing was just being established, when the literary still had the prestige it earlier enjoyed in the age of the manuscript, but when it could be widely and inexpensively disseminated through the agency of the press. 3 Scott wrote of Vitruvius 'Upon this obsequious, short, and unprospering architect the whole glory of antiquity was destined to be concentrated. Europe, for three hundred years, bowed to him as to a god.' But it is Renaissance classicism, an architecture built around Vitruvius's text, which Scott admires: it is admirable because it responds to the aesthetic taste of those 'whose minds are not disembodied', for 'Our aesthetic taste is partly physical; and while mathematical "proportion" belongs to the abstract intellect, aesthetic "proportion" is a preference in bodily sensation'.4 Thus we transcribe ourselves into terms of architecture and feel a real physical discomfort in a top-heavy building, and we transcribe architecture into terms of ourselves and see a spire soar, while in fact gravity is pulling it downwards. For Scott, this haptic, somatic view of architecture is universal, it is an unconscious process like breathing. 5

The processes of which we are least conscious are precisely the most deep-seated and universal and continuous, as, for example, the process of breathing. And this habit of projecting the image of our own functions upon the outside world, of reading the outside world in our own terms, is certainly ancient, common and profound.

Importantly, Scott relates these notions to the employment of mass and line and space in the design of buildings. And of these it is space that is 'the very centre of architectural art', for buildings create spaces in which we can stand and breathe and expand, the very epitome of bodily wellbeing. This emphasis on space relates Scott's work to those modernist theories of architecture that also purported space to be the essence of architecture. The overt rejection of textuality by this theory (which is to say its repudiation of Vitruvius) also links him to modernism.

A very current writer who also returns to the body in his advancing of a particular mode of building is Kenneth Frampton. His so-called 'critical regionalism' is to be an architecture that resists consumer capitalism, and it is to do so by eschewing the visual and emphasising the tactile apprehension of building: 6

One has in mind a whole range of complementary sensory perceptions which are registered by the labile body: the intensity of light, darkness, heat and cold; the feeling of humidity; the aroma of the material, the almost palpable presence of masonry as the body senses its own confinement; the momentum of an induced gait and the relative inertia of the body as it traverses the floor; the echoing resonance of our own footfall.

But the kind of dilemma that one senses in Scott's book returns here. Frampton problematises his own arguments by occasionally calling on Victor Hugo's Notre
3. Geoffrey Scott, The Architecture of Humanism, New York: W W Norton \& Company, 1974; p. 146.

4. Scott, p. 156.

5. Scott, p. 162 .

6. Kenneth Frampton, Towards a Critical Regionalism', in The AntiAesthetic, Hal Foster ed, Port Townsend, Washington: Bay Press, 1983; p. 28. 
7. Umberto Eco, 'Function and Sign: The Semiotics of Architecture', in Signs, Symbols, and Architecture, G Broadbent, R Bunt, \& C Jencks eds, Chichester: John Wiley \& Sons, 1980 ; p. 36.

8. Ferdinand de Saussure, Course in General Linguistics, London: Fontana/Collins, 1974; p. 23.
Dame de Paris, a book which describes architecture in altogether other terms - not those of the nature of that body, but of cultural history - and which argues against any possibility for a vigorous tectonic culture now at all. For Hugo, print has simply displaced architecture as the privileged encoding device for culture; architecture now finds its legitimacy chiefly serving as a metaphor for print. The piles of print we produce are the new tower of Babel.

Scott's book and the new classicisms which it is currently being used to endorse, and Frampton's curiously old-fashioned theory (it is like a repeat of fifties theories of regionalism) both deserve a great deal more attention. However, the texts I want particularly to examine here are some papers by the American archaeologist/art historian/semiotician Donald Preziosi and two books by him (Architecture, Language and Meaning and The Semiotics of the Built Environment) and a long paper by Umberto Eco, 'Function and Sign: the Semiotics of Architecture'.

But before proceeding I want to note that in Lévi-Strauss, in Scott, and in Frampton, some cognisance is at least implicitly given to the written and/or printed which in some way problematises the view of architecture as an anthropocentric and anthropomorphic building practice. The role of the written is attended to by Eco in his paper: he distinguishes 'codes of reading (and of construction) of the object', and codes of design which precede the object. And though allowing that these codes of design might have their own interest for the semiotician, might indeed demonstrate the 'entire gamut of signs proposed by Peirce', he describes them as notational codes, a means to transcribe the built object (even before it exists), just as to transcribe spoken language there are conventions for representing such elements as sounds, syllables, or words'.7 Thus are architectural writing, drawing, photography, and architectural speaking always bracketed and put aside, as notational codes which find their end and which are superseded in the built, in the tectonic. No attention has to be paid to them, no matter how interesting they may be, because ultimately they do not matter. Only architecture's embodiment as building does. If drawing, photography, etcetera, do usurp our attention, they are to be stigmatised for failing to keep their place as simple communicational tools in service of the tectonic. In particular, it has been architectural photography which has been indicted for this impropriety, indicted on moral grounds.

To anyone who has read Of Grammatology all this must sound familiar. There Derrida writes of condemnations of writing for its tyranny and pathological behaviour, condemnations repeated by Ferdinand de Saussure, founder, originator, of 20th century semiotics. Saussure: 'Language and writing are two distinct systems of signs, the second exists for the sole purpose of representing the first.'8

But writing is not content with such secondary status and it 'manages to usurp the main role'. It does so firstly by failing to represent the spoken sound of words and 
then, by a false authority, insisting that speech match these misrepresentations. Linguistics, here the model for a wider semiotics, is to examine the monstrous effects of writing upon language. 'Linguistics should put them into a special compartment for observation: they are teratological cases.' Derrida places Saussure into a tradition of Western metaphysics: 9
9. Saussure, p. 32; Jacques Derrida, Of Grammatology, Baltimore: The John Hopkins University Press, 1976; p. 38.

10. Eco, p. 11.

11. Eco, p. 37

Sin has been defined often ... as the inversion of the natural relationship between the soul and the body through passion. Saussure here points at the inversion of the natural relationship between speech and writing. It is not a simple analogy: writing, the letter, the sensible inscription, has always been considered by Western tradition as the body and matter external to the spirit, to breath, to speech, to the logos. And the problem of soul and body is no doubt derived from the problem of writing from which it seems - conversely - to borrow its metaphors.

The suppression of writing in the philosophy of language in its privileging of speech, and of verbal and graphic codes in architecture in its privileging of the building, are the same. But graphic practices are incidentally conceded the pivotal role by Eco in the semiotics of architecture which he attempts to outline in 'Function and Sign' in a brief aside he makes near the beginning of the piece. Contemplating the 'point of view of the man who started the history of architecture' who finds his way into a cave to shelter from a storm, Eco asks himself, how would the concept of 'sheltering cave' that this projected primitive might usefully formulate there become more than an element in a purely private tectonic code? How would the code become shared, social, which is to say properly a code? Eco answers:

... he would probably be able at this point, to communicate the model of the cave to other men, by means of graphic signs. The architectural code would generate an iconic code, and the 'cave principle' would become the object of communicative intercourse.

But if the code is conditional on this communicative intercourse, then it is an iconic, graphic code which has generated the tectonic code, and not vice versa. Some kind of graphic marking is present in architecture at its origins as Eco describes them. His lack of interest in this, his relegation of the graphic to a merely notational role is, then, curious.

Eco's initial description of what constitutes architecture, what I would call the tectonic, is wide. 'It should be noted that the term architecture will be used in a broad sense here, indicating phenomena of industrial design and urban design as well as phenomena of architecture proper.10 $\mathrm{He}$ is ambivalent about whether architecture has any bounds. On the one hand he decides it would be better to pass over the notion that the built might find in Euclidean geometry a second level of articulation equivalent to that of the distinctive features found in language because 'this geometric code would not pertain specifically to architecture'.11 On the other he discovers on examining what architects do in practice 'that in the last analysis 
12. Eco, p. 51.

13. Donald Preziosi, Architecture, Language and Meaning, The Hague: Mouton, 1979; p. 33. the architect has to elaborate his sign vehicles and messages in relation to systems of meanings that lie outside his province'. The series of social exigencies which the architect addresses constitutes what Eco calls an anthropological code. He suggests that an intimation of the nature of this code is found in Edward T Hall's work on proxemics, significative spatial behaviour in animals and humans. But the discussion of proxemics is confusing (confusing because Hall's work is confusing): it is never clear whether proxemics is a matter of culture, or whether it is a natural phenomenon. Studies of various animal species have demonstrated species-specific (and species-universal) flight distances, attack distances, and so on: for living creatures space is meaningful. Proxemics, then, belongs to the realm of nature. But we are told by Eco that: 'The problem of proxemics has been to investigate the codification of such phenomenon in human culture, and to investigate the different codifications of them in different human cultures.' 12

He then devotes some pages to reporting Hall's analyses of space types and distance types (intimate to public), and differences between these in American and German cultures. The reader is left with the implication that either differences between species are a matter of their possessing different cultures, or that Americans are different from Germans, and from the French, Japanese, and Arabs, insofar as these nationalities each constitute different natural species.

Preziosi also hovers around the boundaries of the natural and the cultural (as if they exist). Firstly, when he considers the origins of architecture: he pays some attention to the scrappy remains of a hut found near Nice and speculates about the emergence of culture. To engage in cooperative behaviour early hominids would need to have had both verbal skills and a tectonic code - they would have needed meeting places. (Preziosi here reads like Vitruvius.) Secondly, he is near the nature/culture divide when he considers the limits of that which he is theorising about when he theorises a semiotics of the built environment. 13

From the perspective of the formations and communicative signals of other species, human artifactual formations have a curiously 'blurred' identity. Whereas many nonprimates such as birds and fishes often respond to a single patch of colour o: bodily gesture .... the primate more consistently responds to the appearance of an entire body in space, its posture and soundings, in the context of the history of previous encounters with that other individual.

If meaning is articulated only at the level of entire social encounters, can different semiotic aspects be singled out in any way to be separately theorised? Are there boundaries within culture? Preziosi in effect answers this question right at the beginning of The Semiotics of the Built Environment when he insists that an architectonic system can get along without building as such. It can on the one hand assimilate the natural environment, and on the other it can also be played out somatically, proxemically, as in a group of people meeting in a field, seated in a 
circle. He writes: 14

But if the latter observation is so, then it is important to be clear about the 'boundaries' of architectonic communication, representation and expression vis-a-vis other nonarchitectonic signings in the visual channel. We must distinguish between 'somatotopic' behaviours wherein bodies construct spatial frameworks architectonically, and somatic gesturings wherein body parts such as the limbs and portions of the face are employed in support of a verbal message.

Here the boundary between the tectonic and the linguistic is determined in the different demands that each places on the body. This economy of demands can be supposed to subsume other demands that further, only apparently independent, semiotics might make.

Eco's view and Preziosi's can be taken as complementary, for the one establishes the bases of the tectonic, the built, in proxemics, in the body, in the somatic, and the other posits that its boundaries are there. Architecture, identified with building, begins and ends in the body. Presumably, then, what gives some construction its status in the tectonic code is that the human body can in some way be imputed to be its guarantor, and it the body's deputy, its transcription. The built is valid when it transcribes the somatic, just as writing is traditionally validated in its transcription of the spoken (and as graphic practices in architecture are validated by building). This likeness in these views of building and writing is not accidental. Preziosi's work has been elaborated under the eye of linguistic and literary theorist Roman Jakobson, at least metaphorically: at the beginning of his Architecture, Language and Meaning, Preziosi offers Jakobson a special acknowledgement. Writing in the same tone as Saussure on the relationship of the written and the spoken, Jakobson (with Morris Halle) has described writing as supplementary and as parasitic auxiliary. 15 Buildings, then, are dead letters for the liveliness of bodily experience.

Now if one is going to construct a semiotic theory of something, the way to proceed, I suppose, is to describe its signifiers and its signifieds, the mode of their correlation, and then, bearing in mind that such descriptions are heuristic fictions, to describe how the thing being theorised operates as a code. Which is to say, how the fiction of system is always stretched, tested, threatened, and how codes and languages come to have histories. This, at least, is how Eco proceeds in his A Theory of Semiotics.

In Eco's few allusions to the tectonic signifier in 'Function and Sign' it is seen as being a 'spatial form' that concretises significant proxemic distances (a table physically establishes a spatial separation between people, the scope of that separation being accorded meaning in the proxemic code). In his 1972 paper 'A Componential Analysis of the Architectural Sign /Column/" Eco distances himself from a spatial orthodoxy he saw operating in architecture - scholarship has its own
14. Preziosi, The Semiotics of the Built Environment, Bloomington: Indiana University Press, 1979; p. 6.

15. Roman Jakobson \& Morris Halle, Fundamentals of Language, The Hague: Mouton, 1956; p. 17. 
16. Eco,'A Componential Analysis of the Architectural Sign/Column/', in Semiotica, Vol. 5, 1972, p. 100.

17. Preziosi, The Non-Dichotomy of Sensory and Grammatical Relationships: Toward a Relational Theory of the Built Environment', in The Second LACUS Forum 1975, Peter A Reich ed, Columbia, South Carolina: Hornbeam Press, 1976; p. 634.

18. Preziosi, 'Language and Perception', The Fourth LACUS Forum 1977, Michel Paradis ed, Columbia: Hornbeam Press, 1978; p. 7. proxemic code, its own significant distances, and techniques for achieving them. This doxa is an aesthetic fallacy, Eco says, which he wishes to dispatch so that architecture can be equated with building; it holds not so much that space is the medium of architecture, rather that architecture is about spatiality. An architectural work, such as Palladio's Rotunda, communicates 'that particular space that is the space conceived by Palladio'.16 As a counter to this Eco discusses a stick thrust into the ground. Both stick and the space gathered by it are elements of a tectonic sign vehicle that may serve to communicate various meanings that can be conventionally correlated with it. And this stick is, of course, a sort of prefigurement of the column Eco goes on to analyse. And the column is not only a mass/space form, but also anthropomorphic, immemorially so.

For Preziosi, space is also the thing in his, scrupulous and sophisticated (but perhaps not quite persuasive) investigations of the architectonic signifier. He argues that it is the space cell which is the maximal formal configuration that can be minimally significative. Approximately, it is the equivalent of the word, or of the phoneme. (It should not be assumed that the space cell is a room - the stick in the ground or the solitary column which Eco considers 'generate' spaces around themselves that constitute space cells in Preziosi's parlance). Space, then, remains privileged, and this is to be taken as a privileging of the body also. 'At its deepest levels, architecture suggests a series of performances or actions performed in space with their own somatic relational geometries'.17 Preziosi believes that the tectonic code, like the linguistic, is ruled by a double articulation: 'As a result of research over the past decade there is no longer any question that both systems are designed according to a principle of "duality of patterning" or "double articulation".'18 Indeed, it seems that for Preziosi double articulation is present everywhere in human semiosis and that it is this which constitutes the nature of the human subject, of subjectivity, our specificity. In the architectonic, the built, this hierarchical principle mediates between a number of different entities - Preziosi terms them features, forms, templates, figures, cells and matrices. It is not important here to know the differences, just that all these things are mediated by a double articulation. This notion is Jakobson's invention. Again Preziosi identifies his work with the linguist's. (It has been Eco, by the way, in this $A$ Theory of Semiotics, who has done most to show that the principle of double articulation is not universal in human semiosis.)

Now for both Eco and Preziosi, the signifieds of the architectonic code are to do with function. Preziosi further aligns himself with Roman Jakobson, discovering the built to have, like the verbal message in Jakobson's view of it, six functions - the referential function (doubly functional as the references that Preziosi describes are references to activity - but form follows function only insofar as following is ascribed by conventions), the aesthetic function, meta-architectonic function, phatic, emotive, conative functions. Eco very explicitly aligns his semiotics of the 
architectonic with the functionalism of Roland Barthes's Elements of Semiology. Barthes wrote of the semantisation of function and utility: '... as soon as there is a society, every usage is converted into a sign of itself; the use of a rain coat is to give protection from the rain, but this use cannot be dissociated from the very signs of an atmospheric situation'.19 Everything, in fact, is semanticised, becomes sign. Eco's functionalism does not, however, recognise any signings which are innate, natural; we are still in the realm of a semiotics of convention and the arbitrary here:20

The object of use is, in its communicative capacity, the sign vehicle of a precisely and conventionally denoted meaning - its function. More loosely, it has been said that the first meaning of a building is what one must do in order to inhabit it....

Stairs and ramps, claims Eco, denote the possibility of vertical access 'according to an immemorial architectural codification'.

But despite Eco's insistence on convention, functionalism has operated in architecture always to veil convention, to naturalise the cultural object. Functionalism occludes the semantic qualities of our artefacts, and does so through an implicit appeal to the supposed universality of bodily experience, to those minimal conditions the body needs for its survival, a vital anthropological minimum, a natural constant, an essence of man. When Manfredo Tafuri writes that during the 18th century 'Psychology, society, man, enter the discourse on architecture', it should be borne in mind that this man, this subject who was placed at the centre of modern architecture was not only constituted psychologically, but also physiologically.21 This subject is still at the centre of Eco's discourse in 'Function and Sign'.

If I were to continue this presentation of a semiotics of the built drawn from Eco's paper and the texts by Preziosi, and to continue to follow the design suggested by Eco's $A$ Theory of Semiotics, at this point I suppose I would consider a theory of sign production, which is to say a study of how we sign, how from the systems of meaning that we each postulate, we get on in negotiating our way in the semiotic universe. Preziosi would claim for the tectonic just the kind of creativity here that is displayed in language - a code with a limited number of elements yields a 'transfinite variety' of formations through the iterative application of rules.22 All this is familiar enough. Eco's position is more interesting, because although he is very concerned with changes in the conventions that underwrite the built world, he has no way of theorising these because he finds that in the tectonic, change seems to be precluded: 23

... what stands out about these codes is that on the whole they would appear to be, as communicative systems go, rather limited in operational possibilities. They are, that is, codifications of already worked out solutions, codifications yielding standardized messages - this instead of constituting, as would codes truly on the model of verbal
19. Roland Barthes, Elements of Semiology, London: Jonathan Cape, 1967; p. 41.

20. Eco, 'Function and Sign', p. 20.

21. Manfredo Tafuri, Theories and History of Architecture, New York: Harper and Row, 1980; p. 80.

22. Preziosi, 'The Network of Architectonic Signs', in Semiotics Unfolding, T Borbe ed, Berlin: Mouton, 1983.

23. Eco, 'Function and Sign', p. 39. 
24. Eco, A Theory of Semiotics, Indiana University Press, Bloomington, 1976, p. 259.

25. Barthes, The Pleasure of the Text, New York: Hill and Wang, 1975; p. 16. languages, a system of possible relationships from which countless significantly different messages could be generated.

A church is a church is a church. A house is a house is a house. A hut is a hut is a hut. And if this is so, might we not suppose that churches and houses and huts are always the same because bodies that always implicitly inhabit them in Eco's theory are always the same? It is the unquestionable constancy of the body that has made it so attractive as a centring metaphor for architectural discourse. But the discourse may pay for this metaphor by being forced into a theoretical bind, and building that maintained allegiances to such theory would be forced into silence. Change could only be considered to occur inexplicably, catastrophically.

I want to leave this speculation and leave Eco's paper too. Nor will I return to Preziosi's writings. Instead I want briefly to turn my attention to Eco's $A$ Theory of Semiotics, in which after the author has introduced a typology of modes of sign production he immediately implies that this typology is fictional since 'what one calls "signs" are the result of many intertwined modes of sign production'.24 $\mathrm{He}$ considers a staircase and finds that at least four of the kinds of sign production which he identifies in his typology are involved in the stair's fabrication and, presumably, its interpretation. The complexity of the relationship between tectonic signifiers and signifieds is iterated in the complexity of the labour involved to produce or understand tectonic signs/messages/texts. The built is textual. (The textuality of the built is further insisted upon in Eco's later The Name of the Rose.) The reified order of the body has been undone, perhaps, as Eco's texts translate each other. A Theory of Semiotics was written after Eco gave up trying to translate his $L a$ Struttura Assente (1968) into English ('Function and Sign' is a translated and revised excerpt from La Struttura Assente). And not least is the body undone as a unifying metaphor insofar as Eco's corpus of works, works which inform and generate one another in an intertextual play of translation, is not uniform, not a corpus at all. The constancy of the author's own body does not guarantee the unity of his texts. The texts fray instead of incorporating. Bearing in mind these dangers to the order of the body in the acts of translation and excerption, the dangers of textuality, textual generation, of the intertext, we can say of Eco's writings on architecture, and Preziosi's too, and many other translations of architectural theory into the jargon of semiotics, that though these translations apparently bolster the traditions of the architectural discourse with the prestige of a philosophy or a science, they also bring with them a tendency not to bolster but to subvert, simply by placing architectural theory into a textual tradition. A tradition in which certain kinds of uncomfortable questions can be asked of architecture, certain possibilities allowed to play.

Perhaps, for instance, the body itself is textual. In The Pleasure of the Text Roland Barthes 25 records that 
Apparently Arab scholars, when speaking of the text, use this admirable expression: the certain body. What body? We have several of them; the body of anatomists and physiologists, the one science sees or discusses; this is the text of grammarians, critics, commentators, philologists (the pheno-text). But we also have a body of bliss consisting solely of erotic relations, utterly distinct from the first body: it is another contour, another nomination; thus with the text: it is no more than the open list of the fires of language.... The pleasure of the text is irreducible to physiological need.

Perhaps the body is not a principle of unity, of wholeness, of integration. In another piece, Barthes 26 writes:

Here is what I did with my body one day: at Leysin, in 1945, in order to perform an extrapleural pneumothorax operation, a piece of one of my ribs was removed, and subsequently given back to me, quite formally, wrapped up in a piece of medical gauze.... For a long time I kept this fragment of myself in a drawer... [But] then, one day, I flung the rib chop and its gauze from my balcony, as if I were romantically scattering my own ashes, into the rue Servandoni, where some dog would come and sniff them out.

Perhaps the body is not the seat of human being. Jean Baudrillard:27

... this body, our body, often appears simply superfluous, basically useless in its extension, in the multiplicity and complexity of its organs, its tissues and functions, since today everything is concentrated in the brain and in the genetic codes, which alone sum up the operational definition of being.

Perhaps bodies are not always and everywhere the same; perhaps

... there exists no pregiven human body as such, but rather the whole historical range of social experiences of the body, the whole variety of bodily norms projected by a series of distinct historical 'modes of production' or social formations ... .

\section{I cite Fredric Jameson.28}

Who knows what the body was that first entered the cave, that first made the hut? Perhaps it was a woman's.
26. Barthes, Roland Barthes, New York: Hill and Wang, 1977; p. 61.

27. Jean Baudrillard, 'The Ecstacy of Communication', in The Anti-Aesthetic, Hal Foster ed, Bay Press, Port Townsend, Washington, 1983, p. 129.

28. Fredric Jameson, 'Architecture and the Critique of Ideology', in Architecture, Criticism, Ideology, Joan Ockman ed, Princeton Architectural Press, Princeton, New Jersey, 1985, p. 51. 